\title{
Nobel-díj a cirkadián ritmus genetikai szabályozásának felfedezéséért
}

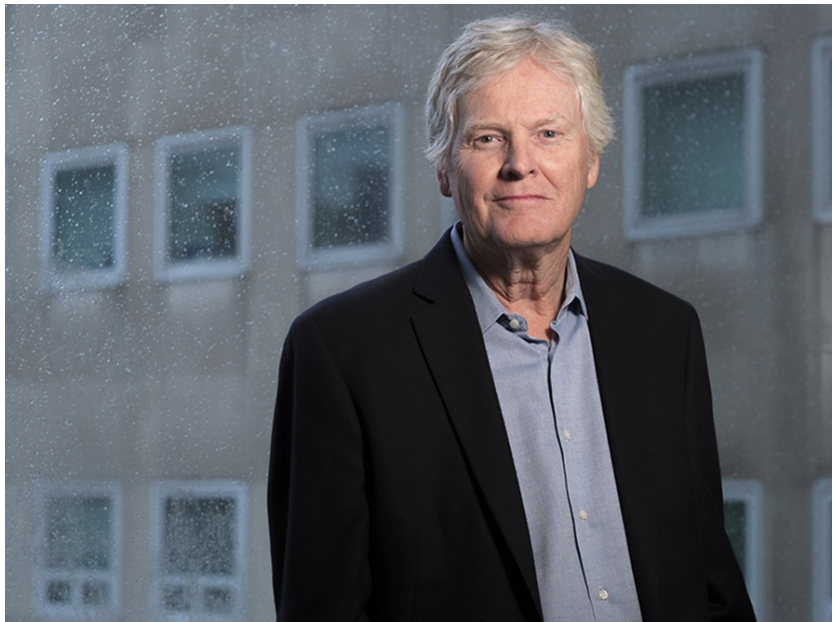

A több mint 100 évvel ezelőtt alapított Nobel-díj a kutatói életpálya legnagyobb elismerése, amely a díjazottak intézményei számára is rendhagyó megbecsülés. Az idén az élettani és orvostudományi Nobel-díjat a Rockefeller Egyetem egyik kutatója, a Genetikai Laboratórium vezetője, Michael W. Young vehette át a cirkadián ritmus molekuláris genetikai szabályozása területén elért, több évtizedes kutatómunkája elismeréseként. Az elismerésben részesült társkutatók Jeffrey C. Hall és Michael Rosbash, mindketten a Brandeis Egyetem kutatói. Az első áttörő eredményük, 1984-ben, a Drosophila melanogaster genomjában a cirkadián ritmus megtartásáért felelős period gén izolálása és karakterizálása volt. Young laboratóriumában számos további, a cirkadián ritmus szabályozásában szerepet játszó gént fedeztek fel. Ezek közül különösen fontos szerepet játszik a timeless gén, amelynek terméke a period gén által kódolt proteinnel interakcióban szabályozza a biológiai óra múködését. Teljesgenom-szekvenálással igazolták, hogy a Drosophila idegrendszerében jelen lévő génállomány 6-7\%-ának szerepe van a cirkadián ritmus szabályozásában. Young munkacsoportja azt is bizonyította, hogy az alvás-ébrenlét ritmus emberben ugyanúgy, mint a Drosophilákban, genetikailag meghatározott és szabályozott. A génaktiválódás a napi biológiai ritmusban óramúszerúen következik be, és a szervezet biológiai múködésének más területeire is kiterjed, pl. az anyagcsere-folyamatokra, az immunitásra, a tanulásra és a memóriára. Ezt korábban már töb- ben feltételezték, de először bizonyítani Young és munkatársai tudták. A Young-Hall-Rosbash-elmélet szerint tehát a cirkadián ritmus genetikai szabályozása az evolúció során konzerválódott.

A felfedezés fontos része az alvás előidézéséért felelős gének múködésének leírása. A belső óra ritmusát szabályozó gének és proteinek funkcióinak megismerése új lehetőségeket nyit olyan emberi betegségek gyógyításában, mint pl. az alvászavarok és a depresszió. A génaktiválódás ritmusának gyógyszeres befolyásolása teljesen új alapokra helyezheti ezeknek a népbetegségeknek a kezelését, és megoldási lehetőséget nyithat nagy távolságra rövid idő alatt utazók jet-lag betegségének modern terápiájára vagy az éjszakai ügyeletben dolgozók alvásbiológiai ritmusának befolyásolására.

Véletlen egybeesés, hogy a Nobel-díj és a Rockefeller Egyetem alapításának éve egyaránt 1901. Aligha tekinthető azonban véletlennek, hogy az elmúlt 116 évben a Rockefeller Egyetemen kutatók közül 25-en kapták meg a legmagasabb rangú kutatói elismerést. Néhány, kémiai kategóriában odaítélt díjtól eltekintve azok mindegyikét az élettani és orvostudományi kategóriában nyerték el, ami önmagában is jelzi ennek az egészen sajátos struktúrájú és szellemiségű, páratlan színvonalú, ugyanakkor szinte családias hangulatú egyetemnek az orvosbiológiai kutatásokban betöltött vezető szerepét.

Young tudományos géniusza rendkívüli szerénységgel, emberi alázattal és tisztelettel társul. A Rockefeller Egyetem elnöke, Richard P. Lifton, aki maga is genetikus kutató, az intézményi ünnepségen és sajtótájékoztatón tartott beszédében kiemelte, hogy még soha nem találkozott olyan szerény Nobel-díjas kutatóval, mint amilyen Michael W. Young. Saját szavaival: „I do not know if the Nobel prize has ever been given to a nicer person."

Young tudásában és karakterében valóban kifejeződik mindaz, amit általában Rockefeller Egyetemnek nevezhetünk.

(Maródi László dr., Semmelweis Egyetem, Budapest, Mária u. 41., 1085 Rockefeller University, New York, 1230 York Avenue, NY 10065 e-mail: marodi.laszlo@med.semmelweis-univ.hu; lmarodi@rockefeller.edu) 